\title{
The Effect of Test Words on Phonological Error Patterns in Typically Developing Children
}

\author{
Minkyeong $\mathrm{Pi}^{\mathrm{a}}$, Seunghee $\mathrm{Ha}^{\mathrm{b}}$ \\ ${ }^{a}$ Graduate Program in Speech Language Pathology, Hallym University, Chuncheon, Korea \\ ${ }^{b}$ Depart Division of Speech Pathology and Audiology, Audiology and Speech Pathology Research Institute, Hallym University, Chuncheon, Korea
}

\author{
Correspondence: Seunghee $\mathrm{Ha}, \mathrm{PhD}$ \\ Division of Speech Pathology and Audiology, \\ Audiology and Speech Pathology Research \\ Institute, Hallym University, 1 Hallymdaehak-gil, \\ Chuncheon 24252, Korea \\ Tel: $+82-33-248-2215$ \\ Fax: +82-33-256-3420 \\ E-mail: shha@hallym.ac.kr
}

Received: April 5, 2020

Revised: May 14, 2020

Accepted: May 14, 2020
Objectives: The frequency of occurrence of phonological error patterns may vary depending on test words with different phonological environments. This study aims to examine whether the phonological error patterns in typically developing children appear differently depending on the test words by implementing two phonology and articulation assessment tools. Methods: The Assessment of Phonology and Articulation for Children (APAC) and Korean Articulation Phonology Profile (K-APP) were evaluated on 193 children aged 2-9 years, and phonological error patterns were analyzed using the same criteria. The phonological environments of test words were compared for each test tool, and the phonological errors which were produced three or more times by each child were considered as error patterns, of which occurrence frequencies were compared between the assessment tools. Results: The K-APP consists of test words with longer syllables and fewer consonant clusters than the APAC. In the K-APP, the frequency of affricates and fricatives was lower compared to the APAC. In the K-APP, the error patterns of whole words such as syllable deletion/reduction and consonant harmony occurred more frequently than in the APAC, because the number of syllables of the test words in the K-APP were longer compared to the APAC. In the APAC, the error patterns of phonemes such as stopping, affrication, and interdentalization occurred more frequently than with the K-APP, because the APAC had a higher proportion of fricatives and affricates. Conclusion: This study suggested that we should consider the effect of test words on phonological error patterns. The study also examined developmental and non-developmental phonological error patterns of Koreanacquiring children using the two articulation and phonology assessments.

Keywords: Phonological error patterns, Test words, Phonological environment, 2- to 9-year-old, Korean-acquiring children
음운 오류패턴은 Stampe (1979)의 자연 음운론(natural phonology)에서 주장한 음운 변동(phonological process)에 기반을 두고 있다. 즉 음운 변동이란 아동이 체계적이지만 무의식적으로 자신 의 음운 규칙을 적용하는 정신적 작용(mental operation)을 반영한 다는 개념이다. 한 낱말기 무렵에는 음운 능력의 제한으로 인해 오 류가 많지만, 아동이 자라면서 성인 형태와 일치하도록 오류패턴을 점진적으로 소거해간다(Donegan \& Stampe, 1979, p. 126).

일련의 규칙에 따라 말소리 패턴을 산출하는 것을 설명하기 위 해 여러 음운 이론이 제시되었다 (Ingram, 1976, p. 3-4). 언어 습득
과 발달 과정에서 아동이 단어를 단순화시켜 발음하는 패턴을 음 운 변동이나 음운 규칙을 통해 설명할 수 있다(Ingram, 1976). 또한 개별적인 말소리 대치를 검토하는 것과는 달리, 음운 변동은 말소 리 환경, 음절 구조 및 음운 자질 대조의 효과를 모두 포함하는 개 념이라고 하였다(Khan, 1982). Stackhouse와 Wells (1997, p. 197, 2001, p. 410)는 아동의 음운 발달에서 음절 구조와 말소리를 통째 로 습득하며 나타나는 '전체 단어' 시기 이후에 분절음 수준에서 '체계적 단순화(systematic simplification)'를 보이는 시기가 나타 난다고 언급하였다. 이때 체계적 단순화의 예로 파열음화 같은 음 
운 변동을 들었다.

개별 말소리 오류만으로 아동이 가진 조음음운능력 전부를 설 명하기는 어렵다. 따라서 선행 연구에서는 아동의 음운 특성을 정 확하게 파악하기 위해서 개별 말소리 정확도뿐만 아니라 음운 오류 패턴을 살펴보아야 한다고 제안하였다(Bernthal \& Bankson, 1998). 따라서 다수의 연구자들이 대단위 연구를 통해 아동의 말소리 발 달뿐 아니라 음운 오류패턴의 변화 추이를 살펴보았다. 이 중 Dodd, Holm, Zhu와 Crosbie (2003)는 3-6세 아동 684명을 대상으로 음 운 발달을 살펴보았다. Dodd 등(2003)은 음운 오류패턴(phonological error pattern)을 아동이 목표 단어를 실현하고자 할 때 조 음음운능력의 제한점으로 인해 목표 형태를 그대로 산출하지 못 하고 말소리가 일관적으로 변화하는 경향성이라고 정의하였다. 아 동이 단순히 1 회 음운 오류를 보인다면 아동이 음운 오류를 일관 적으로 보인다는 경향성을 주장하기 어렵다. 따라서 음운 오류가 비슷한 음운 환경에서 일반적으로 5 회 이상, 최소 2 회 이상 일관적 으로 나타났을 때 이를 음운 오류패턴으로 특정하였다. 이 연구에 서는 음운 오류패턴을 '연령에 적절한(age-appropriate) 오류패턴', '지연된(delayed) 오류패턴', '특이한(unusual) 오류패턴'으로 분류 하였다. 연령에 적절한 오류패턴은 같은 연령대 아동의 $10 \%$ 이상 아동이 사용하는 오류패턴으로 활음화, 탈파찰음화, 전방화, 자음 군 축약, 약한 강세 음절 생략, 파열음화, 유성음화를 예로 들었다. 지연된 오류패턴은 같은 연령대 $10 \%$ 이상 아동에게서 관찰되지는 않지만 더 어린 연령대 아동에게서 $10 \%$ 이상 관찰되는 오류패턴으 로, 동화, 종성 생략, 반복을 포함하였다. 특이한 오류패턴은 어떤 연령대 아동에게서도 $10 \%$ 이상 나타나지 않으며, 후방화, 파찰음 화, 어두초성 생략, 어중자음 생략, 첨가, 탈비음화, 선호 음소 대치 가이에 해당하였다.

음운 오류패턴 중에서도 특이한 오류와 생략 오류는 말소리장 애 아동의 취약한 말-언어 기저 능력을 반영하는 지표로 꼽힌다 (Macrae \& Tyler, 2014; Preston \& Edwards, 2010; Preston, Hull, \& Edwards, 2013). 예를 들어 말소리장애 아동 중에서도 전형적인 오 류패턴보다 비전형적인 오류패턴을 더 많이 보이는 아동의 경우 말 장애의 중증도가 심하고, 음운인식 능력이 낮으며, 언어장애를 동 반할 가능성이 많다고 보았다. 특히 Macrae와 Tyler (2014)는 특정 음운 오류패턴이 순수 말소리장애 집단 아동보다 언어장애를 동반 한 말소리장애 아동에게서 더 자주 나타난다면, 오류패턴이 전반 적인 언어 결함이나 이후 읽기 문제를 반영할 수 있다고 가정하였 다. 따라서 이들은 3-5세 말소리장애 아동을 대상으로 생략, 대치, 왜곡 오류패턴을 전형적인 오류와 비전형적인 오류로 나누어 살펴 보았다. 연구 결과에 따르면 학령 전기 순수 말소리장애 아동과 언
어장애 동반 말소리장애 아동은 오류패턴의 전형성 유무에 따라 서는 유의한 차이가 없었다고 한다. 반면에 생략 오류는 언어장애 를 동반한 말소리장애 아동이 유의하게 많았고, 왜곡 오류는 순수 말소리장애 아동이 유의하게 많았다고 하였다. 즉, 말소리장애 아 동을 언어장애 동반 유무에 따라 구분하였을 때 비전형적인 오류 패턴에서 유의한 차이가 없었다는 점은 비전형적인 오류 패턴이 넓 게 손상된 언어 시스템을 반영하지 못한다는 점을 시사한다. 반면 에 생략 오류는 말소리장애 아동의 기저 인지-언어적 처리 결함을 반영한다고 여겨지는 음운 오류패턴으로 볼 수 있다. 위 연구들을 종합해보면 음운오류패턴에 대해 정확히 이해하고 분석하는 것은 말소리장애 아동의 강약점이나 예후를 판단하기 위해 중요하다.

한국어 음운 특성이 영어와 다르기 때문에 영어권에서 사용한 음운 오류패턴을 우리말에 그대로 적용하기에는 무리가 있다. 예를 들면 한국어 말소리는 경음이 있으므로(Ha, Johnson, \& Kuehn, 2009), 경음화나 평음화 같은 발성유형에 대한 오류패턴이 나타날 수 있다. 반면 한국어에는 음절내 자음군이 없기 없으므로 자음군 단순화가 출현할 수 없다. 이렇듯 언어권에 따라서도 음운 오류패 턴은 다르게 나타날수 있다(Kim, 2014).

따라서 한국 아동에게서 관찰되는 발달적 음운 오류패턴을 찾 으려는 노력이 있었다. Kim과 Shin (2004)은 우리말 조음-음운평 가(Urimal-Test of Articulation and Phonology, U-TAP)를 통해 2-6세 아동의 생략 및 첨가에 대한 오류패턴의 출현율과 대치 오류 패턴의 출현율을 보고하였다. U-TAP의 검사어는 30 개이며 최대 3 음절로 구성되어있다. 생략 및 첨가 오류패턴 중 2 세 아동에게서 $10 \%$ 이상 나타난 것은 종성 생략, 연구개음 생략, 비음 생략이었으 며, 3 세 이상 아동에게서 나타난 것은 종성 생략, 연구개음 생략, 유 음 생략으로 나타났다. 나머지 생략이나 첨가 오류들 중 또래 아동 에게서 $10 \%$ 이상 사용되는 오류패턴은 없었다. 대치 오류패턴 중 에서 2 세 아동의 $10 \%$ 이상이 사용하는 것은 연구개음의 전설음화, 치조음화, 파열음화, 이완음화, 치조음의 후설음화가 나타났다. 3 세 아동이 $10 \%$ 이상 보인 오류패턴은 연구개음의 전설음화, 4 세 아동 이 $10 \%$ 이상 보인 오류패턴은 이완음화로 나타났다. 앞서 언급된 오류패턴 이외에는 조음위치와 조음방법에 대한 대치 오류패턴 중 연령의 $10 \%$ 이상 아동에게서 보고된 것은 없었다.

다음으로 Kim, Pae와 Park (2007)은 아동용 발음평가(Assessment of Phonology and Articulation for Children, APAC)를 통해 2-6세 아동의 단어단위 오류패턴과 분절음변화 오류패턴에 대해 고찰하였다. 단어단위 오류패턴이 3 회 이상 출현한 아동 중 각 연령 집단에서 $10 \%$ 이상 나타난 오류 패턴을 살펴보면 전형적 어중 단 순화가 2세 후반부부터 4세 전반부까지 나타났으며 반복/자음 조 
화와 어말종성 생략은 2 세 후반부까지 나타났다. 비전형적 어중 단 순화와 어두 초성 생략, 첨가, 도치/이동은 모든 연령대에서 $10 \%$ 이 상 출현하지 않았다. 음소 수준 오류패턴 중 가장 많이 나타난 것은 치조마찰음의 치간음화로 2 세 후반부부터 6 세 전반부까지 $10 \%$ 이 상아동에게서 나타났다. 파찰음-마찰음의 파열음화는 2 세 후반부 터 4 세 후반까지 출현하였으며, 파찰음화-구개음화는 2 세 후반부 터 4세 전반까지 나타난 것으로 보고되었다. 유음 오류 중 단순화 는 3세 후반까지 보고되었으나 비음화와 파열음화는 2세 후반 연 령에서만 관찰되었다. 발성유형에 대한 오류는 긴장음화-탈기식음 화만 2세 후반에 나타났으며 이후 연령에서는 나타나지 않았다. 그 밖의 오류패턴은 모든 연령대에서 $10 \%$ 이상 출현하지 않았다.

$\mathrm{APAC}$ 은 한 음소를 어두, 어중, 어말 위치에서 1 회씩 검사하는 기 존 조음음운 검사도구의 한계점을 보완하고자 개발되었다(Kim, $\mathrm{Pae}, \& \mathrm{Lee}, 2005)$. APAC은 우리말 자음의 출현 빈도를 고려하여 고빈도 자음은 검사어에 더 자주 배치되도록 하였고, 단어 내 위치 뿐만 아니라 인접 음운 문맥도 다양화하여 평가할 수 있도록 검사 어가 선정되었다. 그러나 현재까지 개발된 대부분의 검사도구는 검 사어가 1-3음절로 구성되어 있어서 음절 길이와 구조가 복잡해질 때 아동의 음운 오류패턴을 파악하는데는 한계가 있다. 따라서 검 사어가 1-5음절어로 구성되어 있는 현재 개발 및 표준화작업 중인 조음음운 검사도구와 $\mathrm{APAC}$ 을 비교하고자 한다. 즉, 두 검사 도구 의 검사어 음운 특성을 비교하여 살펴보고, 동일한 아동에게 두 검 사도구를 실시하였을 때 검사도구별 오류패턴의 출현 횟수와 오류 패턴이 나타난 아동 수에 차이가 있는지 살펴보고자 한다.

\section{연구방법}

\section{대상자}

본 연구는 2 세 6 개월에서 9 세 11 개월까지 아동 193 명이 참여하 였다. 아동의 거주 지역은 서울 57 명, 경기 41 명, 강원 77 명, 충청 14 명, 경상 4 명이었으며 남아는 97 명, 여아는 96 명이었다. 연구 대상자 의 인구 통계적 특성은 Table 1에 제시하였다.

대상자는 주양육자나 유치원 및 어린이집 교사에 의해 신체적, 인지적, 신경학적 발달 및 정서와 관련된 의학적인 진단을 받지 않 았으며, 청력 손상이 없고 2주 이상 지속된 삼출성 중이염에 대한 병력이 없는 아동으로 보고되었다. 또한 구강 구조 및 기능에 문제 가 없고 말운동장애나 구개열 병력이 없으며, 유창성 장애가 없는 아동으로 확인되었다.

본 연구는 아동용 발음평가(Assessment of Phonology and Articulation for Children, APAC; Kim et al., 2007) 결과, 자음정확도가 -1
Table 1. Participants' demographic characteristics

\begin{tabular}{lccc}
\hline Age group & $\mathrm{N}$ & Gender (boy:girl) & \% of sample \\
\hline $2 ; 6-2 ; 11$ & 20 & $7: 13$ & 10.36 \\
$3 ; 0-3 ; 5$ & 16 & $11: 5$ & 8.29 \\
$3 ; 6-3 ; 11$ & 16 & $11: 5$ & 8.29 \\
$4 ; 0-4 ; 5$ & 16 & $7: 9$ & 8.29 \\
$4 ; 6-4 ; 11$ & 16 & $9: 7$ & 8.29 \\
$5 ; 0-5 ; 5$ & 16 & $5: 11$ & 8.29 \\
$5 ; 6-5 ; 11$ & 14 & $6: 8$ & 7.25 \\
$6 ; 0-6 ; 5$ & 16 & $4: 12$ & 8.29 \\
$6 ; 6-6 ; 11$ & 16 & $10: 6$ & 8.29 \\
$7 ; 0-7 ; 11$ & 16 & $10: 6$ & 8.29 \\
$8 ; 0-8 ; 11$ & 16 & $10: 6$ & 8.29 \\
$9 ; 0-9 ; 11$ & 15 & $7: 8$ & 7.77 \\
Total & 193 & $97: 96$ & 100.00 \\
\hline
\end{tabular}

$\mathrm{SD}$ (16\%ile) 이하인 아동은 제외하였다. 평가자의 지시를 이해하고 검사를 모두 마친 아동이라면 언어 능력에 따라 대상자를 제한하지 는 않았다.

\section{연구도구}

검사 도구는 한국 조음음운프로파일(K-APP)의 '낱말 검사'와 아동용 발음평가(APAC)의 단어 검사를 사용하였다. 검사 실시 방 법은 기본적으로 아동이 검사어에 해당하는 그림을 보고 단어 이 름을 자발적으로 말하는 것이었다. 아동이 검사어를 모르거나 오 반응을 한 경우 검사자가 검사어를 모델링한 후 다시 말하도록 요 청하였다(예: “이건 ‘매미'에요. 이게 뭐라고 했지요?”).

\section{자료수집}

연구 절차는 한림대학교 생명윤리위원회의 승인(HIRB-2015062-C-CM)을 받아 진행되었다. 모든 아동은 개별적으로 평가가 진행되었으며 유치원/어린이집 혹은 대상자의 가정 내에 있는 독립 된 방에서 검사가 이루어졌다.

평가는 언어병리학 전공 대학원생이 실시하였다. 평가에 앞서 아 동과 친밀감을 형성하기 위해 5 분 내외의 대화나 놀이를 실시하였 다. 아동 반응은 모두 음성 녹음기(SONY ICD-PX333)로 수집되었 다. 아동 반응은 평가 상황에서 바로 전사하였고 이후 녹음 자료를 토대로 전사 결과를 점검 및 보완하였다.

\section{자료분석}

아동 반응에 대한 전사는 평가 상황에서 검사자가 음성 전사한 전사 자료를 기반으로 하였으며, 제 1 저자가 녹음 자료를 다시 듣고 
음성 전사의 정확성을 확인하였다.

\section{음운 오류패턴의 종류}

음운 오류패턴의 선정 및 분석 기준은 Kim과 $\mathrm{Ha}$ (2018)의 기준 을 수정 및 보완하여 사용하였다. Kim과 $\mathrm{Ha}$ (2018)의 연구에서는 전체 단어(단어단위) 오류패턴을 음절 생략, 초성 생략, 어중초성 생략, 종성 생략, 음절 및 음소 첨가, 음절 반복, 자음 조화, 전형적 어중 단순화, 비전형적 어중 단순화로 보았다. 본 연구에서는 앞서 언급된 단어단위 오류패턴과 함께 단어 내 자음의 위치가 서로 바 뀌는 도치(metathesis)와 단어 내 음소 위치가 옮겨가는 이동(migration)을 추가하여 오류패턴을 분석하였고, 초성 생략은 어두초 성 생략과 어중초성 생략으로 나누어 분석하였다.

또한 분절음변화 오류패턴은 $\mathrm{Kim}$ 과 $\mathrm{Ha}$ (2018)의 연구에 제시된 오류패턴 유형을 참조하여 조음 위치에 대한 오류패턴은 연구개음 의 전방화, 양순음화, 치경-경구개음화, 연구개음화, 성문음화, 기타 조음위치 왜곡 오류로 나누었다. 조음 방법에 대한 오류패턴은 선 행 연구의 기준에 자음의 활음화(예: / 바나나/ $\rightarrow[$ 바 j f j ㅏ ] )를 추가하 여 파열음화, 파찰음화, 마찰음화, 탈비음화, 비음화, 유음의 단순 화, 유음의 비음-파열음화, 자음의 활음화, 기타 조음방법 왜곡 오 류로 분류하였다. 발성 유형으로는 긴장음화, 이완음화, 탈기식음 화, 기식음화, 기타 발성유형 왜곡 오류로 나누어 살펴보았다.

\section{음운 오류패턴의 적용}

아동의 산출 형태에서 여러 음운 오류패턴이 동시에 출현하는 경우 말소리 변화의 상호작용을 고려하여 음운 오류패턴을 해석하 였다(Preston \& Edward, 2010). 즉 단어단위 오류패턴과 분절음변 화 오류패턴이 동시에 일어날 수 있음을 고려하였다. 예를 들어 '엘 리베이터'를 [에이비터]로 산출한 경우 단어 내 음절 수가 4음절로 줄었으므로 단어단위 오류패턴 중 ‘음절 생략’을 적용하였으며, 또 한 '엘리'의 어중종성과 어중초성에 해당하는 설측음-탄설음 부분 이 생략되었으므로 분절음변화 오류패턴 중 '유음의 단순화’를 함 께 적용하였다.

\section{신뢰도}

아동 반응에 대한 전사와 음운 오류패턴 분석의 정확성을 판단 하기 위해 전사 신뢰도와 음운 오류패턴 분석 신뢰도를 구하였다. 신뢰도 분석 자료는 무작위로 20 명(전체 자료의 $10.36 \%$ )를 선정하 여 분석하였다. 모든 신뢰도 측정치는 본 연구의 저자 2 명이 독립적 으로 자료를 분석한 뒤 일치도를 살펴보았다.

전사 신뢰도는 아동이 산출한 반응을 저자 2 명이 독립적으로 음
성 전사하여 살펴보았다. 전사 신뢰도는 (저자 2 명이 일치하게 전사 한 음소 수)/(제 1 저자가 전사한 음소 수 $) \times 100$ 으로 산출하였다. 이 때 자음에 대한 전사 신뢰도는 $93.05 \%$, 모음에 대한 전사 신뢰도는 $96.91 \%$, 음소 전체에 대한 전사 신뢰도는 $94.80 \%$ 로 나타났다.

음운 오류패턴 분석 신뢰도를 구하기 이전에 독립적으로 전사한 음성 전사 자료에서 전사가 불일치한 부분을 먼저 합치하였다. 합 치된 음성 전사 자료를 토대로 두 명의 저자가 독립적으로 음운 오 류패턴을 분석하였다. 이때 음운 오류패턴 분석 신뢰도는 (저자 2 명이 일치한 음운 오류패턴 수)/(제1저자가 판단한 음운 오류패턴 수) $\times 100$ 으로 산출하였다. 신뢰도 값은 $96.50 \%$ 로 나타났다.

\section{통계분석}

통계 처리는 SPSS version 25.0 (IBM corp., Armonk, NY, USA) 프로그램을 사용하였다. 검사도구별로 출현 횟수가 다른 오류패턴 을 살펴보기 위해 대응 표본 $t$ 검정(paired $t$-test)을 실시하였다. 동 일한 아동이 검사도구별로 산출한 음운 오류의 횟수를 살펴보기 위해 단어단위 음운 오류패턴과 분절음변화 음운 오류패턴 횟수 를 비율로 환산한 뒤 대응 쌍으로 지정하여 검증하였다. 검사도구 별로 출현할 수 있는 단어단위 오류패턴과 분절음변화 오류패턴의 수를 통제하기 위해 음운 오류패턴을 비율로 바꾸어 자료를 분석 하였다.

단어단위 오류패턴 비율은 아동이 산출한 단어단위 오류패턴 횟수를 각 검사도구의 검사어 수로 나누었다. 즉 아동에게서 검사 도구별로 나타난 단어단위 오류패턴의 횟수를 K-APP 검사어 개수 인 32개로, APAC 검사어 개수인 37개로 나누었다. 마찬가지로 분 절음변화 오류패턴 비율도 K-APP의 전체 음소 수 89개와, APAC의 전체 자음 수 95 개로 나누어 산출하였다. 예를 들면 아동이 '파열 음화' 오류를 K-APP에서 9회, APAC에서 13회 보였다면 K-APP에 서 파열음화산출 비율은 $(9 / 89) \times 100=10.11 \%, \mathrm{APAC}$ 에서 파열음 화산출 비율은 $(13 / 95) \times 100=13.68 \%$ 로 보았다.

다음으로 검사도구 별로 오류패턴을 산출한 아동 수에 차이가 있는지 살펴보기 위해 카이제곱 검정(chi-square test)을 실시하였 다. 아동이 특정 음운 오류를 3 회 이상 산출하였을 때만 오류패턴 을 산출하였다고 간주하여 교차분석하였다. 예를 들어 아동이 '음 절 생략/축약' 오류를 $\mathrm{APAC}$ 에서 2회, $\mathrm{K}-\mathrm{APP}$ 에서 4회 산출하였다 면 APAC에서는 음절 축약이 출현하지 않은 것으로 코딩하고 K-APP 은 출현하였다고 코딩하여 분석하였다. 모든 통계 분석의 유의 수 준은 $p<.05$ 로 설정하였다. 
Table 2. Comparison of test words in the two articulation phonology assessment tools

\begin{tabular}{lcc}
\hline & K-APP & APAC \\
\hline Number of test items & 32 & 37 \\
Number of total syllables & 79 & 77 \\
Number of consonant clusters between syllables & 8 & 14 \\
Number of identical syllable repetitions & 2 & 0 \\
Number of 1 syllable words & $5(15.63 \%)$ & $5(13.51 \%)$ \\
Number of 2 syllable words & $15(46.88 \%)$ & $24(64.86 \%)$ \\
Number of 3 syllable words & $6(18.75 \%)$ & $8(21.62 \%)$ \\
Number of 4 syllable words & $4(12.50 \%)$ & - \\
Number of 5 syllable words & $2(6.25 \%)$ & -
\end{tabular}

$\mathrm{K}-\mathrm{APP}=$ Korean Articulation Phonology Profile ( $\mathrm{Ha}, \mathrm{Kim}, \mathrm{Seo}, \& \mathrm{Pi}$, in press); $\mathrm{APAC}=$ Assessment of Phonology and Articulation for Children (Kim, Pae, \& Park, 2007).

\section{연구결과}

\section{검사도구별 음운 환경 비교}

검사도구별로 검사어 구성을 비교한 것은 Table 2에 제시하였다. $\mathrm{K}-\mathrm{APP}$ 의 문항은 32 개로 검사어는 1-5음절이며 총 79음절로 구성 되어있다. K-APP 검사어의 음절 수를 보면 2음절어가 $46.88 \%$ 로 가 장 높은 비율을 차지하였다. APAC에는 없었던 4,5 음절 단어의 비 율은 총 $18.75 \%$ 로 3 음절어가 차지하는 비율과 같았다. K-APP의 단 어 구조를 살펴보면 1 음절어 중 종성이 없는 단어는 1 개, 종성이 있 는 단어는 4 개였다. 2 음절어 중 종성이 없는 단어는 8 개, 종성이 1 개인 단어는 5 개, 종성이 여러 개인 구조는 2 개였다. 3 음절어는 종 성이 없는 단어가 3 개, 종성이 한 개인 구조는 1 개, 종성이 여러 개 인 단어는 2 개였다. 4 음절어는 종성이 없는 단어가 2 개, 종성이 한 개인 단어가 1 개, 종성이 여러 개인 단어가 1 개이며 5 음절어 2 개는 모두 종성이 한 개인 구조로 이루어져있다. 2-5음절 단어 중 음절 간 자음군의 개수는 8 개이다. 동일 음절이 반복되는 검사어는 2 개 (예: 뽀뽀, 바나나)가 있고, 어중종성과 어중초성이 동일한 음소로 이루어진 검사어는 2개(예: 엄마, 엘리베이터)였다.

$\mathrm{APAC}$ 의 문항은 37 개이며 검사어는 $1-3$ 음절로 총 77 음절이다. $\mathrm{APAC}$ 검사어 음절 수를 살펴보면 2음절어 검사어(64.86\%)가 가 장 높은 비율을 차지했으며 다음으로 3음절어(21.62\%)와 1음절어 (13.51\%) 순으로 구성되었다. APAC의 검사어의 단어 구조를 살펴 보면 1 음절어는 모두 종성이 한 개인 구조로 총 5 개였다. 2 음절어는 종성이 없는 단어가 12 개, 종성이 한 개인 단어가 8 개, 종성이 여러 개인 단어는 4 개였다. 3 음절어는 종성이 없는 단어가 1 개, 종성이 한 개인 단어가 4 개, 종성이 여러 개인 단어가 3 개였다. 2 음절어와 3 음절어에서 어중종성과 어중초성이 연달아 나오는 음절 간 자음
Table 3. Consonants frequency (\%) at K-APP and APAC

\begin{tabular}{|c|c|c|c|c|c|c|c|}
\hline \multirow{2}{*}{$\begin{array}{l}\text { Manner of } \\
\text { articulation }\end{array}$} & \multirow{2}{*}{$\begin{array}{l}\text { Pho- } \\
\text { neme }\end{array}$} & \multicolumn{3}{|c|}{ K-APP } & \multicolumn{3}{|c|}{ APAC } \\
\hline & & $\begin{array}{l}\text { Fre- } \\
\text { quency }\end{array}$ & $\%$ & $\begin{array}{l}\text { Sub } \\
\text { total }\end{array}$ & $\begin{array}{c}\text { Fre- } \\
\text { quency }\end{array}$ & $\%$ & $\begin{array}{l}\text { Sub } \\
\text { total }\end{array}$ \\
\hline \multirow[t]{9}{*}{ Stops } & $p$ & 9 & 9.89 & 46.15 & 9 & 9.47 & 38.95 \\
\hline & $p^{*}$ & 3 & 3.30 & & 2 & 2.11 & \\
\hline & $p^{h}$ & 5 & 5.49 & & 2 & 2.11 & \\
\hline & $t$ & 5 & 5.49 & & 5 & 5.26 & \\
\hline & $t^{*}$ & 1 & 1.10 & & 2 & 2.11 & \\
\hline & $t^{h}$ & 4 & 4.40 & & 2 & 2.11 & \\
\hline & k & 9 & 9.89 & & 11 & 11.58 & \\
\hline & $k^{*}$ & 3 & 3.30 & & 2 & 2.11 & \\
\hline & $k^{h}$ & 3 & 3.30 & & 2 & 2.11 & \\
\hline \multirow[t]{3}{*}{ Affricates } & tc & 2 & 2.20 & 6.59 & 4 & 4.21 & 9.47 \\
\hline & $t \varphi^{*}$ & 1 & 1.10 & & 2 & 2.11 & \\
\hline & $t 6^{h}$ & 3 & 3.30 & & 3 & 3.16 & \\
\hline \multirow[t]{3}{*}{ Fricatives } & s & 4 & 4.40 & 7.69 & 7 & 7.37 & 14.74 \\
\hline & $s^{*}$ & 2 & 2.20 & & 4 & 4.21 & \\
\hline & h & 1 & 1.10 & & 3 & 3.16 & \\
\hline \multirow[t]{3}{*}{ Nasals } & $\mathrm{m}$ & 11 & 12.09 & 28.57 & 8 & 8.42 & 25.26 \\
\hline & $n$ & 10 & 10.99 & & 8 & 8.42 & \\
\hline & y & 5 & 5.49 & & 8 & 8.42 & \\
\hline Liquids & $r / l$ & 10 & 10.99 & 10.99 & 11 & 11.58 & 11.58 \\
\hline Total & & 91 & 100.00 & 100.00 & 95 & 100 & 100.00 \\
\hline
\end{tabular}

K-APP = Korean Articulation Phonology Profile (Ha, Kim, Seo, \& Pi, in press); APAC= Assessment of Phonology and Articulation for Children (Kim, Pae, \& Park, 2007).

군(예: 딸기)의 개수는 14 개였다. 동일 음절이 반복되는 검사어는 없었으며 어중종성과 어중초성이 동일한 음소로 이루어진 겹자음 검사어는 1 개였다(예: 올라가).

$\mathrm{K}-\mathrm{APP}$ 과 APAC의 검사어 내 자음 별 빈도와 비율은 Table 3에 제시하였다. K-APP '낱말 검사'의 검사어는 한국어의 19 개 자음과 단모음 7 개, 이중모음 2 개로 구성되었다. 자음 중 상위 3 위에 속하는 자음은/ㅁ, ㄴ/,/ㅂ, ᄀᄀ, ㄹ/,/프, ᄃ, ㅅ, 이이었다. 조음 위치 별로 출현 비율을 살펴보면 치경음이 $39.56 \%$ 로 가장 많았으며, 양순음 $30.77 \%$, 연구개음 $21.98 \%$, 경구개음 $6.59 \%$, 성문음 $1.10 \%$ 순서로 나타났다. 조음 방법 별로 자음 출현 비율을 살펴보면 파열음 $46.15 \%$, 비음 $28.57 \%$, 유음 $10.99 \%$, 마찰음 $7.69 \%$, 파찰음 $6.59 \%$ 순으로 나 타났다. 전체 모음 중 상위 3 위에 속하는 모음은 / $/ /, / / /, /$ 헤 혹은 ㅐ/였다.

$\mathrm{APAC}$ '단어 검사'의 음소는 한국어 19 개 자음과 단모음 7 개, 이 중모음 5 개로 이루어져있다. APAC 검사어의 상위 3 위 자음은 $/ ᄀ$, ㄹ/, /ㅂ/, /ㅁ, ᄂ, 이이었다. 조음 위치 별로 출현 비율을 살펴보면 치경음이 $41.05 \%$ 로 가장 많았으며, 연구개음 $24.21 \%$, 양순음 $22.11 \%$, 경구개음 $9.47 \%$, 성문음 $3.16 \%$ 순서로 나타났다. 조음 방법별로 자 
음 출현 비율을 살펴보면 파열음 $38.95 \%$, 비음 $25.26 \%$, 유음 $11.58 \%$, 마찰음 $14.74 \%$, 파찰음 $9.47 \%$ 순으로 나타났다. 또한 모음 중 상위 3 위인 모음은/F/,///,/工_/이었다.

\section{검사도구별 오류패턴의 출현 횟수 차이}

검사도구별로 출현 횟수가 다른 오류패턴을 살펴보기 위해 동일 한 아동이 검사도구 별로 산출한 음운 오류의 비율에 대해 대응표 본 $t$ 검증한 결과를 Table 4 에 제시하였다. 그 결과 K-APP이 APAC 에 비해 오류패턴 횟수가 유의하게 많이 나타난 오류패턴은 음절 생략/축약, 어중초성 생략, 첨가, 음절 반복, 자음 조화, 도치/이동, 유음의 비음-파열음화였다. 또한 APAC이 K-APP에 비해 오류패턴 이 유의하게 많이 나타난 오류패턴은 치간음화, 파열음화, 파찰음 화, 기타 방법 왜곡이었다.

Table 4. Ratio of phonological error patterns in K-APP and APAC

\begin{tabular}{lcccr}
\hline Error patterns & \% of K-APP & \% of APAC & $t$ & $p$ \\
\hline Syllable deletion/reduction & 2.12 & 0.07 & -8.657 & $<.001$ \\
Word-medial consonant deletion & 0.50 & 0.14 & -4.015 & $<.001$ \\
Addition & 0.55 & 0.25 & -2.610 & .010 \\
Syllable reduplication & 0.23 & 0.04 & -2.786 & .006 \\
Consonant harmory & 1.31 & 0.46 & -4.380 & $<.001$ \\
Metathesis/migration & 0.37 & 0.06 & -3.328 & .001 \\
Interdentalization & 0.76 & 1.09 & 2.457 & .015 \\
Stopping & 1.02 & 2.16 & 5.978 & $<.001$ \\
Affrication & 0.23 & 0.43 & 2.816 & .005 \\
Nasalization or stopping of liquid & 0.40 & 0.13 & -5.379 & $<.001$ \\
Distortion of manner & 0.08 & 0.25 & 2.754 & .006
\end{tabular}

$\mathrm{K}-\mathrm{APP}=$ Korean Articulation Phonology Profile (Ha, Kim, Seo, \& Pi, in press); APAC= Assessment of Phonology and Articulation for Children (Kim, Pae, \& Park, 2007).

\section{검사도구별 오류패턴이 나타난 아동 수 차이}

각 아동이 동일한 음운 오류를 3 회 이상 보였을 때 오류패턴이 나타났다고 분석하여 2-9세 일반 아동이 사용한 단어단위 음운 오 류패턴을 Table 5에 제시하였다. 전형적 어중단순화는 K-APP과 $\mathrm{APAC}$ 모두 3세 후반까지 관찰되었다. 종성 생략은 K-APP과 APAC 모두 3세 전반까지 산출하였다. 자음 조화는 K-APP에서 2세 후반 과 3 세 전반 아동에게서 관찰되었으나 $\mathrm{APAC}$ 에서는 2 세 후반까지 만 관찰되었다. 음절 생략/축약 오류는 K-APP에서만 2세 후반 아 동에게서 출현하였다. 어중초성 생략, 음절 반복, 비전형적 어중단 순화는 모든 연령 집단에서 $10 \%$ 이상 관찰되지 않았으며, 어두초 성 생략, 첨가, 도치/이동은 전 연령대에서 3 회 이상 사용한 아동이 없었다.

2-9세 일반 아동이 사용한 분절음변화 음운 오류패턴을 Table 6 에 제시하였다. 연령 집단별로 $10 \%$ 이상 아동이 사용한 음소 오류 패턴은 K-APP에서 치간음화가 2세 후반, 3 세 전반, 5 세 전반, 5 세 후반, 7세, 8 세를 제외한 모든 연령에서 출현하였으며, $\mathrm{APAC}$ 에서 치 간음화가 2 세 전반, 5 세 후반을 제외한 모든 연령에서 출현하였다. 파열음화는 K-APP이 2세 후반부터 3세 후반까지 나타났으며 APAC 은 2 세 후반부터 4 세 전반까지 나타났다. 파찰음화는 K-APP에서 3 세 전반에서만 출현하였고 $\mathrm{APAC}$ 에서 2 세 후반, 3 세 전반, 4 세 전 반에서 출현하였다. 유음의 단순화는 두 검사도구 모두 2세 후반부 터 3세 후반까지 출현하였다. 연구개음의 전방화는 K-APP에서는 2 세 후반과 3 세 전반에서, $\mathrm{APAC}$ 에서는 2세 후반에서만 출현하였 다. 유음의 비음-파열음화는 K-APP에서 나타나지 않았고 APAC에 서는 2 세 후반과 3 세 전반에서 출현하였다. 구개음화는 APAC에서 만 3 세 전반 아동에게 출현하였다. 탈기식음화, 기식음화, 연구개음 화, 기타 방법 왜곡, 기타 위치 왜곡은 모든 연령 집단에서 $10 \%$ 이상

Table 5. Number and percentage of children using phonological error patterns of whole word

\begin{tabular}{|c|c|c|c|c|c|c|c|c|c|c|}
\hline & \multicolumn{2}{|c|}{$2 ; 6-2-11(N=20)$} & \multicolumn{2}{|c|}{$3 ; 0-3 ; 5(N=16)$} & \multicolumn{2}{|c|}{$3 ; 6-3 ; 11(\mathrm{~N}=16)$} & \multicolumn{2}{|c|}{$4 ; 0-4 ; 5(N=16)$} & \multicolumn{2}{|c|}{$4 ; 6-4 ; 11(\mathrm{~N}=16)$} \\
\hline & K-APP & APAC & K-APP & APAC & K-APP & APAC & K-APP & APAC & K-APP & APAC \\
\hline $\begin{array}{l}\text { Typical intersyllabic consonant cluster } \\
\text { simplification }\end{array}$ & $9(45.00)$ & $13(65.00)$ & $3(18.75)$ & $3(18.75)$ & $4(25.00)$ & $2(12.50)$ & $0(0.00)$ & $0(0.00)$ & $0(0.00)$ & $1(6.25)$ \\
\hline Final consonant deletion & $6(30.00)$ & $7(35.00)$ & $3(18.75)$ & $3(18.75)$ & $1(6.25)$ & $0(0.00)$ & $0(0.00)$ & $1(6.25)$ & $0(0.00)$ & $0(0.00)$ \\
\hline Consonant harmory & $8(40.00)$ & $2(10.00)$ & $2(12.50)$ & $1(6.25)$ & $0(0.00)$ & $0(0.00)$ & $0(0.00)$ & $0(0.00)$ & $0(0.00)$ & $0(0.00)$ \\
\hline Syllable deletion/reduction & $6(30.00)$ & $0(0.00)$ & $1(6.25)$ & $0(0.00)$ & $1(6.25)$ & $0(0.00)$ & $0(0.00)$ & $0(0.00)$ & $1(6.25)$ & $0(0.00)$ \\
\hline Word-medial consonant deletion & $1(5.00)$ & $1(5.00)$ & $0(0.00)$ & $0(0.00)$ & $0(0.00)$ & $0(0.00)$ & $0(0.00)$ & $0(0.00)$ & $0(0.00)$ & $0(0.00)$ \\
\hline Syllable reduplication & $0(0.00)$ & $0(0.00)$ & $1(6.25)$ & $0(0.00)$ & $0(0.00)$ & $0(0.00)$ & $0(0.00)$ & $0(0.00)$ & $0(0.00)$ & $0(0.00)$ \\
\hline $\begin{array}{l}\text { Atypical intersyllabic consonant cluster } \\
\text { simplification }\end{array}$ & $1(5.00)$ & $0(0.00)$ & $0(0.00)$ & $0(0.00)$ & $0(0.00)$ & $0(0.00)$ & $0(0.00)$ & $0(0.00)$ & $0(0.00)$ & $0(0.00)$ \\
\hline
\end{tabular}

Values are presented as number (\%).

Error patterns in children over $10 \%$ by age were shaded (red color).

The error patterns that did not appear are excluded from this table (e.g., word-initial consonant deletion, addition, metathesis/migration). 


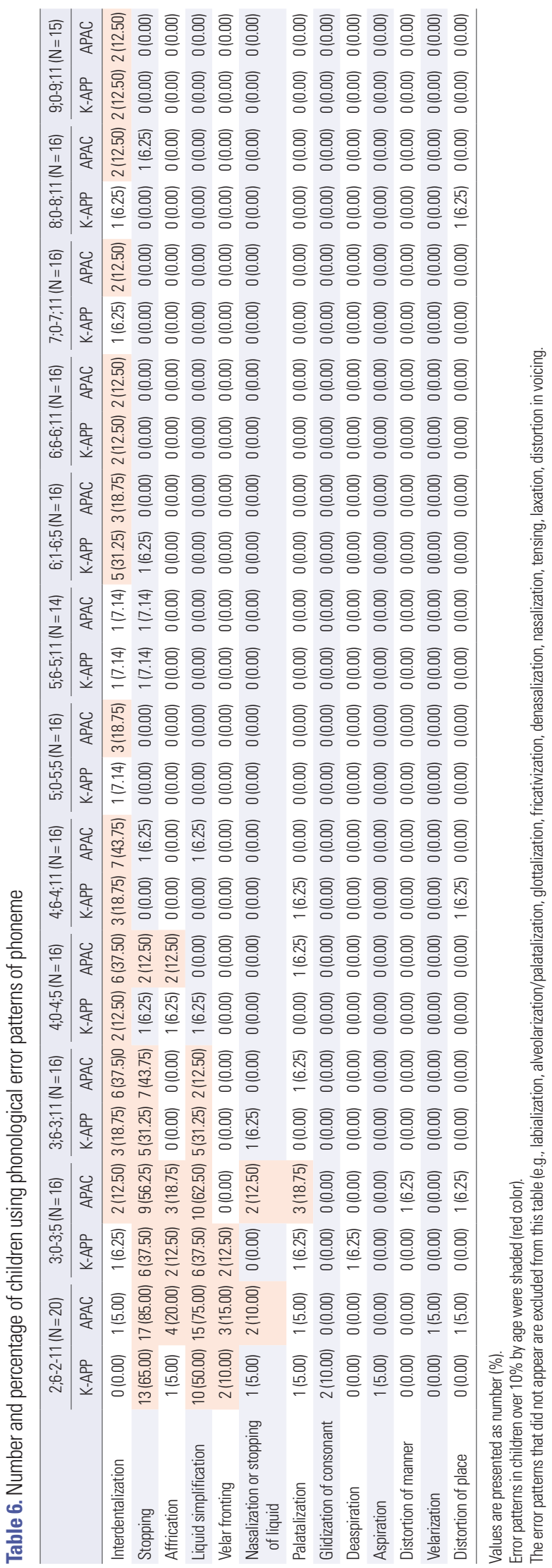

관찰되지 않았으며, 양순음화, 성문음화, 치경경구개음화, 마찰음 화, 탈비음화, 비음화, 긴장음화, 이완음화, 기타 발성 왜곡은 전 연 령대에서 3 회 이상 사용한 아동이 한 명도 관찰되지 않았다.

연령 집단 별로 검사도구에 따라 출현 빈도가 다른 오류패턴을 검증하기 위해 아동이 3 회 이상 산출한 음운 오류를 '오류패턴'으 로 선정하여 연령 집단 별로 카이제곱 검정을 실시하였다. 2 세 후반 아동에게서 검사도구 별로 동일한 음운 오류를 3 회 이상 보인 아동 에 차이가 있는 오류패턴은 음절 생략/축약 $\left(\chi_{(1)}^{2}=7.059, p=.008\right)$, 자음 조화 $\left(\chi_{(1)}^{2}=4.800, p=.028\right)$ 로 모두 K-APP이 APAC에 비해 유 의하게 많은 아동에게서 관찰되었다. 3 세 전반부터 9 세까지 모든 연령 집단에서는 검사도구별로 단어단위 오류패턴과 분절음변화 오류패턴 모두 관찰된 아동 수에 차이가 없었다.

\section{논의 및 결론}

본 연구에서는 K-APP과 APAC의 검사어 음운 환경을 자세히 비 교하여 살펴보았다. 또한 동일한 아동에게 두 검사도구를 모두 실시 하였을 때 검사도구 별 오류패턴의 출현 횟수와 오류패턴을 사용한 아동 수에 차이가 있는지 살펴봄으로써 검사어의 음운 환경이 오 류패턴 출현 횟수에 끼치는 영향에 대해서 살펴보고자 하였다.

먼저 K-APP과 APAC 검사어의 음운 환경을 살펴본 결과, K-APP 과 $\mathrm{APAC}$ 모두 2음절어가 가장 높은 비율을 차지하였지만 K-APP 은 $\mathrm{APAC}$ 에서 포함되지 않은 4-5음절 검사어가 3음절어 검사어와 동일 비율로 구성되었다. 검사어가 길어질수록 아동은 연속된 조 음 움직임에 부하를 받는다. 따라서 일련의 단어 구조를 축약하고 조음 움직임을 줄이려는 생략과 축약 오류가 나타날 수 있다. 따라 서 4-5음절 검사어가 있는 K-APP이 아동에게서 음절 생략이나 축 약과 같은 단어단위 음운 오류패턴이 더 빈번하게 관찰될 가능성 이 있다. 또한 $\mathrm{K}-\mathrm{APP}$ 은 $\mathrm{APAC}$ 에 비해 파찰음, 마찰음의 비율이 적 었다. 해당 음소들은 우리말에서 습득 연령이 늦고 조음 난이도가 높은 음소이다. 따라서 아동이 자신의 제한된 음운 능력을 보완하 기 위해 체계적이고 일관적으로 말소리를 대치하는 분절음변화 오 류패턴을 더 빈번하게 산출할 수 있다. 예를 들어/ㅅ, 씨 / 의 대치나 왜곡 오류로 야기될 수 있는 오류패턴은 파열음화, 파찰음화, 치간 음화, 구개음화가 있다. 또한/ᄌ, ㅊ, 찌의 대치나 왜곡으로 인한 오 류패턴은 파열음화, 치간음화가 있다. 따라서 두 검사도구의 음소 빈도의 차이로 인해 특정 오류패턴 출현 빈도가 달라질 가능성이 있다.

다음은 두 검사도구를 동일한 아동에게 실시함으로써 검사도구 의 음운 특성 상 차이로 인해 실제로 오류패턴의 출현 횟수에 차이 
가 나타나는지 살펴보고자 하였다. 아동에게 관찰된 오류패턴 횟 수의 총합으로 K-APP과 APAC의 오류패턴이 출현한 전체 횟수 차 이를 살펴보았을 때 K-APP이 APAC보다 유의하게 출현 횟수가 높 았던 오류패턴은 (1) 음절 생략/축약, (2) 어중초성 생략, (3) 첨가, (4) 음절 반복, (5) 자음 조화, (6) 도치/이동, (7) 유음의 비음-파열음화 였다. 이 오류패턴들의 출현 횟수가 다른 이유를 살펴보고자 하였 다. 먼저, 음절 생략/축약 오류패턴은 K-APP의 검사어 음절 길이가 $\mathrm{APAC}$ 보다 길기 때문에 많이 출현했을 수 있다. K-APP에서 음절 생략/축약 오류를 보인 아동들은 모두 4 음절어와 5 음절어에서만 음절 생략/축약 오류를 보였다(예: '할아버지' $\rightarrow$ [하부지], '엘리베이 터’ $\rightarrow$ [에이비터], ‘아이스크림' $\rightarrow$ [아이크임] 등). 따라서 K-APP은 일 련의 조음 움직임(sequencing)과 협응력이 떨어져서 단어 전체의 구조를 아직 충실하게 지키지 못하는 아동 평가에 적합할 수 있다.

어중초성 생략은 APAC보다 K-APP에서 더 많이 출현하였다. $\mathrm{APAC}$ 에서 나타난 어중초성 생략의 공통적인 예는 모두 '화장실' 의 어중초성을 생략하는 것이었다(예: [화앙실], [하애딜] 등). K-APP 에서 해당 오류패턴을 사용한 아동의 오류 유형을 살펴보면 3음절 어 ‘목욕탕'은 오류를 보인 아동 6명 모두 [모욕탕]으로 산출하였 다. '선생님'은 2 음절의 초성이나 3 음절의 초성을 생략하여 [성앵님] 혹은 [선생임]으로 발음하였다. 4음절어 '파인애플[파이내플]'은 [파이애플]로 8 회 관찰되었다. 5 음절어인 '엘리베이터'는 음절 축약 과 어중초성 생략이 함께 나타난 [에이에터], [에어에떠]와 같은 형 태로 나타났다. '아이스크림'은 [아이으크임]으로 1 회 관찰되었다. 어중초성 생략의 출현 횟수에 대해 정리하면, 일반적으로 3 음절 이 상 단어에서 해당 오류패턴이 관찰되었다. 따라서 3 음절 이상 검사 어의 비율이 높은 K-APP이 APAC에 비해 어중초성 생략 오류가 더 빈번하게 나타났다고 볼 수 있다.

$\mathrm{K}-\mathrm{APP}$ 과 APAC을 통틀어 2음절어에서 어중초성 생략을 보인 아동은 동일한 아동 1 명으로 2 세 8 개월 남아이다. 해당 아동은 $\mathrm{APAC}$ 과 K-APP의 2음절어에서 어중초성 생략을 총 7회 보였다 (예: '모자' $\rightarrow$ [모아], '찢어' $\rightarrow$ [찌어], '매미' $\rightarrow$ [매이], '악어' $\rightarrow$ [아어] 등). 이 아동은 $\mathrm{APAC}$ 검사 규준상 $18 \% \mathrm{ile}$ 로 일반 아동으로 분류되었으 나 국내외 선행연구에서 일반적으로 비발달적인 오류패턴으로 제 안되는 초성 생략, 첨가, 도치/이동 오류패턴이 관찰되었다(Preston \& Edwards, 2010). 해당 아동은 2세 후반으로 아직 말소리 습득 초 기에 해당하기에 자음정확도만으로 판단한다면 말소리장애로 진 단되지 않을 수 있다. 하지만 아동이 보이는 비발달적 오류패턴은 아동이 전형적인 말소리 습득과정에 있는 것이 아닐 수 있음을 시 사한다. 비발달적인 오류패턴은 인지-언어적 처리에 결함을 반영하 므로 비발달적인 오류패턴을 보이는 아동은 전반적인 언어 및 읽기
문제를 보일 가능성이 높다(Macrae \& Tyler, 2014). 따라서 이 아동 의 조음음운발달 및 언어발달을 주의 깊게 추적하거나 아동의 어 중초성 생략 오류패턴을 적극적으로 중재할 필요가 있겠다.

첨가 오류패턴은 낱말에 음소를 첨가하는 양상으로 해석할 수 있다. K-APP에서 나타난 첨가 오류를 살펴보면, 첨가 오류패턴은 3 음절어 이상 검사어에서 주로 관찰됨을 알 수 있었다. 예를 들어 3음절어 '피아노'는 [피나노], [피라노]로 어중초성 첨가 오류가 나 타났다. 4음절어인 ‘파인애플[파이내플]'은 [파니내플], [파리내플], [파이매이프], [파마마플] 같은 첨가 오류가 나타났다. '미끄럼틀'은 어중종성을 첨가한 [밍크럼틀]과 [밍끄럼틀]이 출현하였다. 5음절 어인 엘리베이터는 어두초성을 첨가하는 오류(예: [헬리베이터], [헬베이터], [네비베이터] [멜리베이터])와 어중초성을 첨가하는 오 류(예: [에이베비터]), 검사어를 축약하면서 어중종성을 첨가하는 오류(예: [엘리벨터])가 나타났다. 마지막으로 5음절어 중 '아이스크 림'은 어두초성을 첨가하는 오류(예: [하키])와 음절을 축약하면서 어중초성이나 어중종성을 첨가하는 오류(예: [아쓸크림], [알츠크 림], [아잉크림], [아리크림])이 나타났다. 본 연구의 일반 아동이 산 출한 대다수의 첨가 오류는 3 음절 이상의 검사어에서 낱말 내 동일 한 음소 또는 동일한 조음방법과 위치의 음소를 첨가한 경우이다. 따라서 넓은 의미로 음소 반복 또는 자음 조화로도 해석할 수 있어 일반적으로 비발달적 오류 패턴으로 분류되는 첨가와는 다른 경향 성을 보였다. 1 음절어나 2 음절어에서 첨가 오류를 보인 경우는 단 2 회로 2 세 후반 아동이 ‘입’ $\rightarrow$ [이뽀], ‘풍선’ $\rightarrow[$ 푸스떠]로 산출하였다. 이는 모음을 첨가한 패턴으로 [이뽀]는/ㄱ// 첨가, [푸스떠]는/ㄱ/ 첨가로 해석할 수 있다. 정리하면 1,2 음절 검사어의 첨가 오류는 2 세 후반 아동에게서 관찰되어 미숙한 조음 움직임으로 인해 산출 된 예로 볼수 있다.

음절 반복은 K-APP에서 9명의 아동에게 13회 나타났으며 APAC 에서는 2 명의 아동에게서 3 회 나타났다. $\mathrm{APAC}$ 에서 음절 반복 형 태는 '사탕’ $\rightarrow$ [탕탕], ‘올라가’’ $\rightarrow$ 올라라], ‘햄버거’ $\rightarrow$ [앰버버]였으나, K-APP에서 나타난 반복 오류는 2음절어 '도둑'이 2회(예: [도도]), 3 음절어 '피아노'가 1회(예: [삐아아]), 4 음절어 '할아버지'는 1회(예: [하바바디]), '크레파스'는 1회(예: [크레트트]), '파인애플'은 3회(예: [파이프프], [파이이트], [타마마플]), '미끄럼틀'은 2회(예: [미뜨끄 그], [크크러틀]), 5음절어 엘리베이터는 1회(예: [엘리리베터]), '아 이스크림'은 2회(예: [아크크림], [아이크크림])으로 나타났다. 즉, $\mathrm{K}-\mathrm{APP}$ 의 반복 오류 13 회 중 10 회가 4,5 음절 검사어에서 나타났다. 이는 검사어의 길이가 길어질수록 아동이 조음 움직임과 구조를 단순화하기 위해음절 반복을 한다는 것으로 볼 수 있다.

자음 조화는 K-APP에서 43 명의 아동에게 총 86 회 관찰되었고 
$\mathrm{APAC}$ 에서 29 명의 아동에게 47 회 관찰되었다. K-APP에서 검사어 길이 별로 자음 조화가 나타난 비율을 살펴보면 1음절어 $5.81 \%$ (5 회), 2 음절어 $18.60 \%$ (16회), 3 음절어 $43.02 \%$ (37회), 4 음절어 $30.23 \%$ (26회), 5음절어 8.14\% (7회)였다. 자음조화는 3음절어(예: '떡볶이' $\rightarrow$ [떡꼬끼], '목욕탕' $\rightarrow$ [모두탕] 등)와 4음절 검사어(예: '미끄럼틀' $\rightarrow$ [미트어틀] 등)에서 가장 빈번하게 나타났다. 2음절 검사어는 전 체 검사어의 약 $47 \%$ 를 차지하지만 자음 조화의 관찰 횟수는 $18.60 \%$ 로 적었다(예: ‘라면' $\rightarrow$ [나넌]). 5음절 검사어인 ‘엘리베이터'와 ‘아이 스크림'은 자음 조화 오류보다 음절 생략/축약으로 오류패턴으로 실현되어 자음 조화가 많이 관찰되지 않았다. 종합하면, 자음 조화 오류는 1,2 음절 검사어에 비해 3,4 음절 검사어에서 나타나기 쉬우 며 검사어 음절 수의 영향을 받았다고 해석할 수 있다.

도치/이동은 K-APP에서는 16 명의 아동에게 23회 관찰되었고 $\mathrm{APAC}$ 에서 3 명의 아동에게 4 회 관찰되었다. K-APP에서 도치/이동 오류가 나타난 검사어를 살펴보면 '도깨비' 7회(예: [도빼기]), '파인 애플' 10 회(예: [파내이플]), ‘크레파쓰' 1회(예: 크예차프), '엘리베이 터(엘레베이터)' 5 회(예: [에이비에터])로 모두 3음절어 이상 검사어 에서 도치/이동 오류가 나타났다. 즉, 도치/이동 오류패턴은 단어가 길어질수록 아동이 음절 배열에 어려움이 보여 단어의 음절 수가 긴 K-APP에서 더 어려움을 겪는다는 것을 알 수 있다.

유음의 비음-파열음화는 K-APP에서 58 명의 아동에게 68 회 관 찰되었고 $\mathrm{APAC}$ 에서는 14 명의 아동에게 24 회 관찰되었다. $\mathrm{APAC}$ 에는 어두초성 /리로 시작하는 검사어가 없기 때문에 유음의 비 음-파열음화는 모두 어중초성 위치에서 나타났다(예: ‘머리' $\rightarrow$ [머 디, '고래’’[고대]). K-APP에서 유음의 비음-파열음화가 나타난 아 동 58 명의 오류 유형을 분석한 결과, 어두초성 /리로 시작하는 검 사어인 '라면'에서만 유음의 비음-파열음화를 보인 아동은 39 명 (67.24\%), 어중초성 /리이 포함된 검사어(예: 크레파스)에서만 유음 의 비음-파열음화를 보인 아동은 12 명(20.69\%), 어두초성과 어중 초성 /리에서 모두 유음의 비음화를 보인 아동은 7명(12.07\%)였다. 이 결과는 어두초성 /리의 조음 난이도가 어중초성 /리에 비해서 도 높아 대치 오류를 빈번하게 일으켰음을 알 수 있다.

단어단위 오류패턴인 음절 생략/축약, 어중초성 생략, 첨가, 음절 반복, 자음 조화 오류패턴은 모두 3음절 이상의 검사어에서 빈번하 게 나타나는 양상을 보여 APAC보다 K-APP에서 유의하게 출현 횟 수가 많았다. 즉 단어단위 오류패턴은 주로 검사어 길이에 영향을 받았음을 알 수 있다. 분절음변화 오류패턴인 파열음화, 파찰음화, 치간음화, 구개음화는 K-APP보다 APAC에서 유의하게 많은 횟수가 관찰되었는데 이는 $\mathrm{APAC}$ 검사어의 구성 음소 중 마찰음, 파찰음이 차지하는 비율이 K-APP에 비해 높기 때문이라는 점을 시사한다.
아동에게 관찰된 오류패턴 횟수의 총합으로 K-APP과 APAC의 오류패턴이 출현한 전체 횟수 차이를 살펴보았을 때 K-APP보다 $\mathrm{APAC}$ 에서 유의하게 많이 출현한 오류패턴은 (1) 치간음화, (2) 파 열음화, (3) 파찰음화, (4) 기타 방법 왜곡이었다. 이러한 결과는 앞 서 언급한 음소 빈도에 영향을 받았다고 추측할 수 있다. 즉, K-APP 은 $\mathrm{APAC}$ 에 비해 치조 마찰음과 파찰음 빈도가 적었으므로 치조마 찰음과 파찰음을 파열음으로 대치하는 파열음화 오류, 치조마찰 음과 파찰음을 치간음으로 대치하는 치간음화 오류가 적었다. 기 타 방법 왜곡이 APAC에서 유의하게 빈번하게 나타난 이유를 살펴 보기 위해 기타 방법 왜곡을 산출한 아동의 오류 형태를 살펴보았 을 때, 2 세 후반과 3 세 초반 아동 3 명(각 1 회)에게서 겹자음화 왜곡 오류(예: ‘나무' $\rightarrow$ [남무], '고래' $\rightarrow$ [골래])가 일어난 것을 제외하고는 모두/ㅅ, 씨/와/, ㅊ/음소에서 '설측음화’ 오류가 관찰되었다. 요 약하자면 동일한 아동에게 두 검사도구를 실시하였을 때 $\mathrm{APAC}$ 에 서 빈번하게 출현한 오류패턴은 모두 / ㅅ, 씨,/ᄌ, ㅉ, ㅊ/와 관련이 있는 오류패턴으로K-APP보다 APAC에서 치조 마찰음, 파찰음 음 소 빈도가 높기 때문에 오류패턴도 빈번하게 난 것이라고 해석할 수 있다.

$\mathrm{APAC}$ 과 K-APP에서 연령별로 오류패턴이 출현한 아동 수 차이 를 검증하였을 때, 2 세 후반 아동에게서 음절 생략/축약과 자음 조 화가 K-APP에서 유의하게 많이 나타났다. 즉, 두 오류패턴 모두 검 사어 길이의 영향을 받아 K-APP에서 유의하게 많은 수의 아동이 산출하였음을 알 수 있다. 3 회 이상 자음조화를 보인 아동을 살펴 보면 K-APP과 APAC 모두 자음조화는 2세 후반부터 3세 전반 아 동까지 나타나 차이가 없는 것처럼 보일 수 있다. 그러나 APAC에 비해 K-APP에서 다음절 검사어가 많았기 때문에 2세 후반 아동의 자음 조화 횟수가 유의하게 많았다는 점을 유의해야 할 것이다.

본 연구에서 단어단위 오류패턴 중 전형적 어중단순화는 3 세 후 반까지 두 검사도구 모두에서 관찰되었고, 종성 생략, 자음 조화는 3 세 전반까지 두 검사도구에서 관찰되었다. 음절 생략/축약은 $\mathrm{K}-\mathrm{APP}$ 에서만 2세 후반 연령에서 관찰되었다. 분절음변화 오류패 턴 중 치간음화는 두 검사도구 모두 대체적으로 3-9세 사이에 나타 나는 경향성을 보였다. 치조 마찰음이나 경구개파찰음 음소 빈도 와 관련이 있는 파열음화, 파찰음화 오류패턴은 K-APP에서는 3세 까지 관찰되었으나 $\mathrm{APAC}$ 에서는 4 세까지 관찰되었다. 유음의 단순 화는 두 검사도구 모두 3세 후반까지 관찰되었다. 유음의 비음/파 열음화와 구개음화, 연구개음의 전방화는 2 세 후반에서 3 세 전반 사이에 APAC에서만 관찰되었다. 즉, K-APP에서 발달적인 음운 오 류패턴은 전형적 어중단순화, 종성 생략, 자음 조화, 음절 생략/축 약, 치간음화, 파열음화, 파찰음화, 유음의 단순화였고, $\mathrm{APAC}$ 에서 
발달적인 오류패턴은 전형적 어중단순화, 종성 생략, 자음 조화, 치 간음화, 파열음화, 파찰음화, 유음의 단순화, 유음의 비음/파열음 화, 구개음화, 연구개음의 전방화였다. 본 연구에서 K-APP과 APAC 에서 발달 경향성에 차이를 보인 오류패턴은 음절 생략/축약, 유음 의 비음/파열음화, 구개음화, 연구개음의 전방화이다. 앞서 논의한 대로 음절 생략/축약은 K-APP의 검사어 음절수가 APAC에 비해 길기 때문에 일반 아동에게서도 관찰될 가능성이 높아져서 두 검 사도구에서 차이가 나타났다. 또한 구개음화나 연구개음의 전방화 는 치조 마찰음이나 파찰음이 많고, 전설 모음 앞 연구개음이 더 많 은 $\mathrm{APAC}$ 의 검사어 특성상 $\mathrm{K}-\mathrm{APP}$ 과 차이를 보였다는 점을 알 수 있다.

다음으로 $\mathrm{APAC}$ 에 제시된 오류패턴과 와 본 연구의 K-APP과 $\mathrm{APAC}$ 의 오류패턴 양상의 차이점에 대해 살펴보았다. Kim 등 (2007)과 본 연구대상자의 오류패턴 양상이 상이한 것은 긴장음화 와 탈기식음화, 그리고 음절 반복이었다. Kim 등(2007)에서는 '긴 장음화 - 탈기식음화가 발달적인 오류패턴이었던 반면에 본 연구 에서는 $10 \%$ 미만 아동에게서 관찰된 오류패턴이었다. 선행연구에 서는 대치음이 경음으로 같은 오류패턴인 긴장음화와 탈기식음화 를 하나로 묶었기 때문에 검사에서 3 회 이상 관찰될 가능성이 높았 을 것이다. 따라서 긴장음화와 탈기식음화를 따로 센 본 연구 결과 와 다른 양상을 보였다. 또한 음소 빛 음절을 반복하는 오류패턴은 선행 연구에서 전체 구조를 조화하는 것으로 해석하여 '반복·자음 조화를 하나의 오류패턴으로 간주하였다. 따라서 선행 연구에서 는 ‘반복. 자음조화’가 발달적인 오류패턴으로 나타났으나음절 반 복과 자음 조화를 따로 살펴본 본 연구는 음절 반복이 비발달적인 오류패턴으로 나타날수 있다.

본 연구 결과 중 같은 아동에게 두 개의 조음음운 검사도구를 실 시하였을 때 검사도구에 따라 발달적 오류패턴과 비발달적 오류패 턴의 양상이 달라지는지 살펴보았다. 이때 APAC에서는 발달적 오 류패턴이지만 K-APP에서는 어떤 연령대에서도 $10 \%$ 이상 아동에 게서 관찰되지 않은 오류패턴은 유음의 비음/파열음화, 구개음화 였다. 유음의 비음/파열음화와 구개음화를 K-APP에서 2회 이상 관찰되었을 때 '오류패턴'이라고 간주하여 분석하면 APAC과 동일 하게 2 세 후반이나 3 세 전반의 $10 \%$ 이상 아동에게서 관찰되는 발 달적 오류패턴으로 나타난다. 따라서 K-APP 검사도구에서 유음의 비음-파열음화와 구개음화는 오류패턴의 선정 기준을 3 회로 적용 하는 것이 다소 엄격한 기준일 수 있다는 점을 시사한다.

반대로 $\mathrm{APAC}$ 에서는 어떤 연령대에서도 $10 \%$ 이상 아동에게서 관찰되지 않은 오류패턴이었으나 K-APP에서는 발달적인 오류패 턴으로 나타난 것은 음절 생략/축약과 자음의 활음화였다. 음절 생
략/축약은 APAC에서는 모든 연령대 아동에게서 나타나지 않았지 만 K-APP에서는 2세 후반과 3 세 전반 아동의 $10 \%$ 이상에게서 나 타났다. 실제로 음절 생략/축약 오류는 3 세 이하의 어린 연령의 자 발화에서 쉽게 관찰되는 오류패턴이다. 다만 APAC의 단어 수준에 서는 검사어 길이가 짧아서 음절을 생략하거나 축약하는 오류가 잘 드러나지 않다가 검사어의 길이가 긴 K-APP에서 아동의 취약점 이 드러난 것으로 볼 수 있다. 즉, $\mathrm{K}-\mathrm{APP}$ 의 검사어 중 약 $18 \%$ 를 차 지하는 4,5 음절 검사어로 인해 음절 생략/축약 오류가 $10 \%$ 이상 아동에게서 나타난 것으로 해석할 수 있다. 음절 생략/축약이 나타 난 아동의 모두가 4,5 음절에서 오류가 나타났음을 감안하였을 때 검사어의 길이가 최대 3 음절인 $\mathrm{APAC}$ 에서는 음절 생략/축약이 나 타나지 않다가 4-5음절 검사어가 구성된 K-APP에서 음절 생략/축 약이 비로소 나타나기 시작했다고 해석할 수 있다.

$\mathrm{APAC}$ 에서는 모든 연령대에서 $10 \%$ 이상 아동에게 나타나지 않 았으나 K-APP에서 $10 \%$ 이상 아동에게서 관찰된 자음의 활음화는 2세 후반 아동 두 명에게서 관찰되었는데 오류 형태는 '바나나' $\rightarrow$

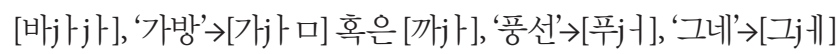
였다. 이를 통해 만 2 세까지는 자음의 활음화 오류가 $10 \%$ 이상 아 동에게서 관찰된 발달적인 오류패턴이라고 볼 수 있다. 자음을 활 음으로 대치하는 오류는 아동이 후두 위쪽 조음 기제를 거의 사용 하지 않은 오류로 '생략' 오류와 패턴이 유사하다. 다시 말하면 K$\mathrm{APP}$ 은 검사어 길이가 다른 검사도구에 비해 길기 때문에, 일반 아 동이라도 어린 연령이라면 음절과 음소 위치를 정확하게 지키는 것 이 어렵다. 즉 단어 산출할 때 아동이 받는 산출 난이도가 높아져 생략 오류나 자음을 단순화 시키는 활음 대치 오류를 더 빈번하게 보였다고 사료된다.

본 연구는 검사어의 음운 환경이 상이한 두 가지 조음음운 검사 도구를 동일한 아동에게 실시하였을 때 오류패턴의 출현 횟수나 관찰된 아동 수의 차이를 살펴보았다. 연구 결과를 종합해보면 $\mathrm{K}-\mathrm{APP}$ 은 검사어 길이가 길기 때문에 검사어 길이에 영향을 받을 수 있는 단어단위 오류패턴이 연령 집단의 $10 \%$ 이상 출현할 가능 성이 높아진다. 또한 K-APP은 마찰음, 파찰음의 구성 비율이 낮기 때문에 마찰음, 파찰음과 연관된 분절음변화 오류패턴은 $\mathrm{APAC}$ 에 비해 출현 횟수가 적을 수 있다. 특히 해석에 유의해야 하는 점은 동 일한 음운 오류가 3회 관찰되었을 때 아동이 '오류패턴'을 산출하 는 것으로 간주했을 때, APAC 검사에서는 연령 집단의 $10 \%$ 이상 나타난 오류패턴이 K-APP에서는 연령 집단의 $10 \%$ 미만으로 나타 나거나 아예 출현하지 않게 되는 경우이다. 본 연구에서 이런 오류 패턴은 유음의 비음-파열음화와 구개음화로 해당 오류패턴의 출현 빈도가 낮아 ‘3회 이상 출현'을 오류패턴 선정 기준으로 삼기 어려 
울 수 있다. 이런 오류패턴을 검증하고 명확히 밝혀 K-APP 검사어 조건에서는 '2회 이상 출현' 시에 '오류패턴'으로 선정하는 것도 염 두에 두어야 할 것이다. 본 연구는 검사어 변인이 달랐을 때 동일한 아동일지라도 오류패턴 양상이 다르게 나타날 수 있다는 점을 시 사하였다. 따라서 후속 연구에서는 검사도구 별로 발달 양상이 다 르게 나타난 음운 오류패턴에 대해 오류패턴 별로 선정 기준점을 달리 적용하여 가장 최선의 기준점을 검증해야 할 것이다. 궁극적 으로 말소리장애 아동 진단 시 중요한 정보인 한국 아동의 발달적, 비발달적 오류패턴을 정립해야 할 것이다.

\section{REFERENCES}

Bernthal, J., \& Bankson, N. (1998). Articulation and phonological disorders (4th ed.). Boston: Allyn \& Bacon.

Dodd, B., Holm, A., Zhu, H., \& Crosbie, S. (2003). Phonological development: a normative study of British English-speaking children. Clinical Linguistics \& Phonetics, 17(8), 617-643.

Donegan, P. J., \& Stampe, D. (1979). The study of natural phonology. In D. Dinnsen (Ed.), Current approaches to phonological theory (pp. 126-173). Bloomington: Indiana University Press.

Ha, S., Johnson, C. J., \& Kuehn, D. P. (2009). Characteristics of Korean phonology: review, tutorial, and case studies of Korean children speaking English. Journal of Communication Disorders, 42(3), 163-179.

Ha, S., Kim, M., Seo, D. G., \& Pi, M. (in press). Korean Articulation Phonology Profile. Seoul: Human Brain Research and Consulting.

Ingram, D. (1976). Phonological disability in children (Vol. 2). London: Edward Arnold.

Khan, L. M. (1982). A review of 16 major phonological processes. Language, Speech, and Hearing Services in Schools, 13(2), 77-85.
Kim, M., \& Ha, S. (2018). Developing weighted phonological mean length of utterance and testing the validity. Communication Sciences \& Disorders, 23(3), 692-702.

Kim, M. J., Pae, S. Y., \& Lee, S. E. (2005). The development of the 'Test of Articulation for Children': concurrent validity. Korean Journal of Communication \& Disorders, 10(1), 82-96.

Kim, M. J., Pae, S., \& Park, C. I. (2007). Assessment of phonology for children (APAC). Seoul: Human Brain.

Kim, S. J. (2014). Phonological error patterns of conversational speech produced by 2-and 4-year-old children. Communication Sciences \& Disorders, 19(3), 361-370.

Kim, Y. T., \& Shin, M. J. (2004). Urimal Test of Articulation and Phonology $(U-T A P)$. Seoul: Hakjisa.

Macrae, T., \& Tyler, A. A. (2014). Speech abilities in preschool children with speech sound disorder with and without co-occurring language impairment. Language, Speech, and Hearing Services in Schools, 45(4), 302-313.

Preston, J., \& Edwards, M. L. (2010). Phonological awareness and types of sound errors in preschoolers with speech sound disorders. Journal of Speech, Language, and Hearing Research, 53(1), 44-60.

Preston, J. L., Hull, M., \& Edwards, M. L. (2013). Preschool speech error patterns predict articulation and phonological awareness outcomes in children with histories of speech sound disorders. American Journal of SpeechLanguage Pathology, 22(2), 173-184.

Stackhouse, J., \& Wells, B. (1997). Children's speech and literacy difficulties: A psycholinguistic framework (Vol. 1). London: Whurr.

Stackhouse, J., \& Wells, B. (2001). Children's speech and literacy difficulties: Identification and intervention (Vol. 2). London: Whurr.

Stampe, D. (1979). A dissertation on natural phonology. New York: Garland. 


\section{국문초록}

\section{검사어에 따른 음운 오류패턴 비교}

피민경 $\cdot$ 하승희 ${ }^{2}$

'한림대학교 대학원 언어병리청각학과, ${ }^{2}$ 한림대학교 언어청각학부, 청각언어연구소

배경 및 목적: 음운 오류패턴의 음운 환경이 다른 검사어에 따라 출현 빈도가 달라질 수 있다. 본 연구는 두 가지 조음음운검사도구를 실시하여 일반 아동의 음운 오류패턴이 검사어에 따라 다르게 나타나는지 알아보고자 하였다. 방법: 2-9세 일반 아동 193명에게 APAC 와 K-APP의 단어 수준 검사를 실시하였으며 동일한 기준으로 음운 오류패턴을 분석하였다. 검사도구별로 음운 환경을 비교하였고 검 사 도구 별로 음운 오류패턴이 나타난 총 횟수와 오류패턴이 확인된 아동 수의 차이를 비교하였다. 결과: K-APP은 APAC에 비해 음절 길이가 길고 음절 간 자음군이 적은 검사어로 구성되어있다. K-APP은 파찰음과 마찰음의 빈도가 $\mathrm{APAC}$ 에 비해 적었다. K-APP은 다음 절 검사어 비율이 높아음절생략/축약, 자음조화 같은 전체단어 오류패턴의 횟수가 유의하게 많았고 $\mathrm{APAC}$ 은 파찰음과 마찰음 비율이 높아 파열음화, 파찰음화, 치간음화 같은 음소 오류패턴 횟수가 유의하게 많았다. 논의 및 결론: 본 연구는 검사어가 음운 오류패턴에 영향을 끼칠 수 있다는 점을 시사하였다. 또한 두 가지 조음음운평가를 사용하여 한국 아동의 발달적인 음운 오류패턴과 비발달적인 음운 오류패턴을 제안하였다.

핵심어: 음운 오류패턴, 검사어, 음운 환경, 2-9세, 일반 아동

\section{참고문헌}

김민정, 배소영, 박창일(2007). 아동용 발음평가(APAC). 서울: 휴브알앤씨.

김민정, 배소영, 이성은(2005). ‘아동용 조음검사'의 개발. 언어청각장애연구, 10(1), 82-96.

김민정, 하승희(2018). 가중평균음운길이의 개발과 타당도 검증. Communication Sciences \& Disorders, 23(3), 692-702.

김수진(2014). 자발화에 나타나는 발달적 음운오류패턴. Communication Sciences \& Disorders, 19(3), 361-370.

김영태, 신문자(2004). 우리말 조음음운평가(U-TAP). 서울: 학지사.

하승희, 김민정, 서동기, 피민경(출판중). 한국 조음음운프로파일(K-APP). 서울: 휴브알앤씨.

\section{ORCID}

피민경(제1저자, 대학원생 https://orcid.org/0000-0002-9093-8005); 하승희(교신저자, 교수 https://orcid.org/0000-0003-2133-3720) 